\title{
Antioxidant effects of insulin-like growth factor-I (IGF-I) in rats with advanced liver cirrhosis
}

\author{
María García-Fernández 1,2, Inma Castilla-Cortázar*1,2,3,2, Matías Díaz- \\ Sanchez ${ }^{1}$, Iñigo Navarro 4 , Juan Enrique Puche ${ }^{2,3}$, Alberto Castilla ${ }^{5}$, \\ Amelia Díaz Casares ${ }^{2,3}$, Encarna Clavijo ${ }^{6}$ and Salvador González-Barón ${ }^{2}$
}

\begin{abstract}
Address: ${ }^{1}$ Department of Physiology, School of Medicine, University of Navarra, Pamplona, Spain, ${ }^{2}$ Department of Human Physiology. School of Medicine, University of Málaga, Spain, ${ }^{3}$ Department of Physiology, School of Medicine, University of San Pablo-CEU, Madrid, Spain, ${ }^{4}$ Department of Chemistry, School of Medicine, University of Navarra, Pamplona, Spain, ${ }^{5}$ Department of Internal Medicine, Hospital Sierrallana, Torrelavega. Cantabria, Spain and 'Department of Microbiology, School of Medicine, University of Málaga, Spain

Email: María García-Fernández - igf@uma.es; Inma Castilla-Cortázar* - iccortazar@uma.es; Matías Díaz-Sanchez - mdiaz@chdo.osakidetza.net; Iñigo Navarro - inavarro@unav.es; Juan Enrique Puche - puche@uma.es; Alberto Castilla - med003047@saludalia.com; Amelia Díaz Casares - adcasares@iib.uam.es; Encarna Clavijo - eclavijo@uma.es; Salvador González-Barón - sgonzalez@uma.es

* Corresponding author
\end{abstract}

Published: 03 March 2005

BMC Gastroenterology 2005, 5:7 doi:10.1 186/147/-230X-5-7
Received: 22 July 2004

Accepted: 03 March 2005

This article is available from: http://www.biomedcentral.com/I47I-230X/5/7

(C) 2005 García-Fernández et al; licensee BioMed Central Ltd.

This is an Open Access article distributed under the terms of the Creative Commons Attribution License (http://creativecommons.org/licenses/by/2.0), which permits unrestricted use, distribution, and reproduction in any medium, provided the original work is properly cited.

\begin{abstract}
Background: The exogenous administration of Insulin-like Growth Factor-I (IGF-I) induces hepatoprotective and antifibrogenic actions in experimental liver cirrhosis. To better understand the possible pathways behind the beneficial effect of IGF-I, the aim of this work was to investigate severe parameters involved in oxidative damage in hepatic tissue from cirrhotic animals treated with IGF-I $\left(2 \mu \mathrm{g} .100 \mathrm{~g}^{-1}\right.$. day $\left.\mathrm{y}^{-1}\right)$. Iron and copper play an important role in oxidative mechanisms, producing the deleterious hydroxyl radical $(* \mathrm{OH})$ that peroxides lipid membranes and damages DNA. Myeloperoxidase (MPO) and nitric oxide (NO) are known sources of free radicals and induce reduction of ferritin- $\mathrm{Fe}^{3+}$ into free $\mathrm{Fe}^{2+}$, contributing to oxidative damage.
\end{abstract}

Methods: Liver cirrhosis was induced by $\mathrm{CCl}_{4}$ inhalation in Wistar male rats for 30 weeks. Healthy controls were studied in parallel $(n=10)$. Fe and $\mathrm{Cu}$ were assessed by atomic absoption spectrometry and iron content was also evaluated by Perls' staining. MPO was measured by ELISA and transferrin and ferritin by immunoturbidimetry. iNOS expression was studied by immunohistochemistry.

Results: Liver cirrhosis was histologically proven and ascites was observed in all cirrhotic rats. Compared to controls untreated cirrhotic rats showed increased hepatic levels of iron, ferritin, transferrin $(p<0.01)$, copper, MPO and iNOS expression $(p<0.01)$. However, IGF-treatment induced a significant reduction of all these parameters $(p<0.05)$.

Conclusion: the hepatoprotective and antifibrogenic effects of IGF-I in cirrhosis are associated with a diminution of the hepatic contents of several factors all of them involved in oxidative damage. 


\section{Background}

Insulin-like growth factor-I (IGF-I) is an anabolic hormone produced in different tissues in response to growth hormone (GH) stimulation [1]. Liver synthesis of IGF-I accounts for $90 \%$ of the circulating peptide. In cirrhosis the reduction of receptors for GH in hepatocytes and the diminished synthesis ability of the hepatic parenchyma cause a progressive fall in serum IGF-I levels. The clinical impact of the decreased in IGF-I production in advanced cirrhosis is largely unknown [2-5]. Recent studies from our laboratory in rats with carbon tetrachloride-induced cirrhosis have demonstrated that short courses of treatment with low doses of IGF-I are able to produce systemic beneficial effects [6-13] and are associated to hepatoprotective $[14,15]$ and antifibrogenic [16] effects.

In order to give a better insight into the pathways by which IGF-I seems to exert its the hepatoprotective and antifibrogenic actions, this study was aimed at analyze several parameters involved in oxidative stress or inflammation in the liver, such as metals ions (iron and copper), iron transport and store proteins (transferrin and ferritin) and enzymes (myeloperoxidase -MPO- and inducible nitric oxide synthase -iNOS-) both in IGF-I treated and untreated cirrhotic rats.

Metal ions, such as iron and copper, exhibit the ability to produce reactive oxygen species, resulting in lipid peroxidation, DNA damage, depletion of sulfhydryls and altered calcium homeostasis [17-19]. Iron-dependent processes play a pivotal role in the development of oxidativeinduced cell injury. Specifically, the generation of hydroxyl radicals from hydroperoxide and the formation of aldehydes and lipid peroxy radicals from lipid hydroperoxides are catalyzed by redox-active metals, including iron and copper $[17,20,21]$. MPO and NO are known sources of free radicals and induce reduction of ferritin- $\mathrm{Fe}^{3+}$ into free $\mathrm{Fe}^{2+}$ contributing to oxidative damage $[22,23]$.

\section{Methods \\ Induction of liver cirrhosis}

Cirrhosis was induced as previously described $[9,12]$. Briefly, male Wistar rats (3 weeks old, 130-150 g) were subjected to $\mathrm{CCl}_{4}$ inhalation (Merck, Darmstadt, Germany) twice a week for 11 weeks with a progressively increasing exposure time from 1 to 5 minutes. From that time until the $30^{\text {th }}$ week rats were exposed to $\mathrm{CCl}_{4}$ once a week for $3 \mathrm{~min}$. During the whole period of cirrhosis induction animals received Phenobarbital (Luminal, Bayer, Leverkusen, Germany) in the drinking water (400 $\mathrm{mg} / \mathrm{L}$ ). Rats were housed in cages placed in a room with 12-hour light-dark cycle and constant humidity and temperature $\left(20^{\circ} \mathrm{C}\right)$. Both food (standard semipurified diet for rodents; B.K. Universal, Sant Vicent del Horts, Spain) and water were given ad libitum. Healthy, age and sexmatched control rats were maintained under the same conditions but receiving neither $\mathrm{CCl}_{4}$ nor Phenobarbital.

All procedures were performed in conformity with The Guiding Principles for Research Involving Animals [24].

\section{Study design}

The treatment was administrated the last three weeks $\left(27^{\text {th }}\right.$ $-30^{\text {th }}$ ) of $\mathrm{CCl}_{4}$ exposure (from day 0 to day $22^{\text {nd }}$ ). In the morning of day 0 , animals were weight and blood samples were drawn from the retroocular venous plexus from all rats with capillary tubes (Marienfeld, Germany) and stored at $-20^{\circ} \mathrm{C}$ until used for analytical purposes. Cirrhotic rats were randomly assigned to receive either vehicle (saline) $(\mathrm{CI}, \mathrm{n}=10)$ or recombinant human IGF-I (Pharmacia-Upshon, Sweden) $\left(2 \mu \mathrm{g} \times 100 \mathrm{~g} \mathrm{bw}^{-1} \times\right.$ day $^{-1}$ in two divided doses, subcutaneous) $(\mathrm{CI}+\mathrm{IGF}, \mathrm{n}=10)$ for three weeks. Control rats $(\mathrm{CO}, \mathrm{n}=10)$ received saline during the same period. The last dose of IGF-I was administrated the day $21^{\text {st }}$ at 6 p.m.

In the morning of the $22^{\text {nd }}$ day, animals were weight and killed by decapitation. After the abdominal cavity was opened, the liver was dissected and weight. A sample from the left major liver lobe was processed for histological examination (fixed in Bouin's solution). The rest of liver samples were stored at $-80^{\circ} \mathrm{C}$.

\section{Liver histopathology, Perls'stain and immunohistochemistry}

Bouin-fixed tissues were processed and sections (4- $\mu \mathrm{m}$.) were stained with Haematoxylin and Eosin and Masson's trichrome. Liver cirrhosis was diagnosed according to the criteria previously described $[14,16]$. Liver sections were stained for iron detection with Perls' Prussian Blue $[25,26]$. A semiquantitative score was given since 0 to 6 points: 0 when no staining was observed, as it was observed in controls; 6 points were assigned to sections with the maximal staining (full staining), that it was observed in liver macrophages and fibrous septa from cirrhotic rats; $2-5$ points when the staining were less extent. Four fields from each preparation ( $\times 100$ magnification) were evaluated twice by two different observers. The arithmetical mean of the two punctuations was taken as the final score.

Immunohistochemical staining of iNOS in paraffin sections $(4 \mu \mathrm{m})$ was performed using an avidin-biotin peroxidase technique as described by Shu el al. [27], with some modifications. The primary antibody anti-iNOS (1:500) was obtained from Oxford Biomedical Research, INC, NS 01 . The procedure for negative controls was performed by omission of antigen retrieval part of the protocol. The positive staining was estimated blindly in the entire 
Table I: Hepatic levels of some parameters involved in oxidative damage in the three experimental groups.

\begin{tabular}{|c|c|c|c|}
\hline & $\begin{array}{l}\text { Control group } \\
(C O, n=10)\end{array}$ & $\begin{array}{c}\text { Untreated cirrhotic rats } \\
(\mathrm{Cl}, \mathrm{n}=\mathrm{I0})\end{array}$ & $\begin{array}{l}\text { Cirrhotic rats treated with IGF-I } \\
\qquad(\mathrm{CI}+\mathrm{IGF}, \mathrm{n}=10)\end{array}$ \\
\hline $\mathrm{Fe}(\mu \mathrm{g} / \mathrm{mg}$ protein) & $2.74 \pm 0.19$ & $12.87 \pm 1.90 * *$ & $6.80 \pm 1.10^{\&}$ \\
\hline $\mathrm{Cu}(\mu \mathrm{g} / \mathrm{mg}$ protein $)$ & $160 \pm 5$ & $1626 \pm 678 * * *$ & $500 \pm 258 \&$ \\
\hline Ferritin (ng/mg prot) & $32.60 \pm 3.80$ & $97.60 \pm 12^{* *}$ & $67.70 \pm 11.30^{2}$ \\
\hline Transferrin ( $\mu \mathrm{g} / \mathrm{mg}$ protein $)$ & $8.46 \pm 1.05$ & $10.96 \pm 0.98 * *$ & $8.36 \pm 0.36^{\&}$ \\
\hline MPO(ng/mg protein) & $1.02 \pm 0.02$ & $1.25 \pm 0.04 * *$ & $1.06 \pm 0.07 \&$ \\
\hline iNOS (AU) & $1.20 \pm 0.64$ & $5.53 \pm 0.54^{\text {**** }}$ & $2.88 \pm 0.68^{\&}$ \\
\hline
\end{tabular}

$\&_{p}<0.05$ between $\mathrm{Cl}$ and $\mathrm{Cl}+$ IGF groups; ${ }^{* *} \mathrm{p}<0.01$ and ${ }^{* * *} \mathrm{p}<0.001 \mathrm{Cl}$ vs $\mathrm{CO}$ groups; $\mathrm{AU}=$ arbitrary units

preparation by using a numerical scored from 1 to 8 points attending to the staining area and the intensity of the color. The arithmetical mean of the two evaluations was taken as the final score.

\section{Analytical methods}

\section{Sample processing}

Hepatic samples were homogenized in a Potter homogenizer in 7 volumes of cold buffer $(0.1 \mathrm{M}$ Tris- $\mathrm{HCl}, 0.25 \mathrm{M}$ sucrose, $\mathrm{pH}=7.4$ ) containing $5 \mathrm{mM}$ 2-mercaptoethanol, $0.5 \mu \mathrm{g} / \mathrm{mL}$ Leupeptin, $0.7 \mu \mathrm{g} / \mathrm{mL}$ pepstatin A and $100 \mu \mathrm{g} /$ $\mathrm{mL}$ PMFS. Fibrous parts and unbroken cells debris were eliminated by centrifugion at $500 \mathrm{~g}$ for $5 \mathrm{~min}$. Supernatans were used as the whole homogenate.

\section{Analytical determinations on hepatic homogenates}

MPO was measured by ELISA, using a commercial kit from BIOXYTECH ${ }^{\circledast}$ (OXIS Int. Portland, OR, USA). Transferrin and ferritin were determined by immunoturbidimetry, using a Hitachi 710 autoanalyzer (Roche Diagnostic, Basilea, Switzerland) and kits for clinical human, from the same laboratory. MDA was assessed after heating samples at $45^{\circ} \mathrm{C}$ for 60 minutes in acid medium. It was quantitated by a colorimetric assay using LPO-586 (Bioxytech; OXIS International Inc., Portland, OR, USA), which after reacting with MDA, generating a stable chromophore that can be measured at $586 \mathrm{~nm}$ (Hitachi U2000 Spectro; Roche). Total proteins were assessed by Bradford's method [28].

\section{Determinations of iron and copper by Atomic Absorption} Spectrophotometry

Representative samples (approximately $1 \mathrm{~g}$. of each rat liver) were collected, weighed and later dried in stove $\left(70^{\circ} \mathrm{C}\right)$ to constant weight. Iron and copper concentrations were determined by flame atomic absorption spectrophotometry (Perkin Elmer 460, Uberlingen, Germany) [25].

\section{Statistical Analysis}

Data were expressed as mean \pm SEM. To analyse the homogeneity among groups, Kruskall-Wallis test was used, followed by multiple post-hoc comparisons using Mann-Whitney $U$ tests with Bonferroni adjustment. Any $P$ value $<0.05$ was considered to be statistically significant. Calculations were performed with SPSS program version 6.0 (SPSS Inc., Chicago, IL).

\section{Results}

Liver cirrhosis was histologically proven and ascites was observed in all rats treated with $\mathrm{CCl}_{4}$.

Table 1 shows the values of parameters involved in oxidative damage in hepatic homogenates. Compared with healthy controls, untreated cirrhotic rats (CI group) showed increased hepatic levels of the following variables: $\mathrm{Fe}(\mathrm{p}<0.01)$; transferrin and ferritin $(\mathrm{p}<0.01)$; $\mathrm{Cu}$ $(\mathrm{p}<0.001) ; \mathrm{MPO}$ and iNOS expression $(\mathrm{p}<0.001)$. However, cirrhotic animals treated with IGF-I (CI+IGF group) showed significant reductions in hepatic Fe and $\mathrm{Cu}$ contents, ferritin, transferrin and MPO levels and iNOS expression ( $\mathrm{p}<0.05$ for all the parameters).

As shown in Figure 1, untreated cirrhotic rats (CI) have significantly greater scores of iron (ferric iron) in the liver using Perls' Prussian blue staining as compared with controls $(\mathrm{CO}=0.68 \pm 0.11)$ and cirrhotic rats treated with IGF-I $(\mathrm{CI}=5.50 \pm 0.22 ; \mathrm{CI}+\mathrm{IGF}=1.70 \pm 0.40 ; \mathrm{AU}, \mathrm{p}<$ 0.01). As mentioned before, hepatic levels of iron, assessed by atomic absorption spectrophotometry, were also significantly higher in CI group compared to controls and CI+IGF group (see Table 1). On the other hand, hepatic levels of copper were also increased in untreated cirrhotic rats and returned to normal in CI+IGF group.

Figure 2 shows the immunohistochemical expression of iNOS that was increased in CI group compared both to control and $\mathrm{CI}+\mathrm{IGF}$ groups. 

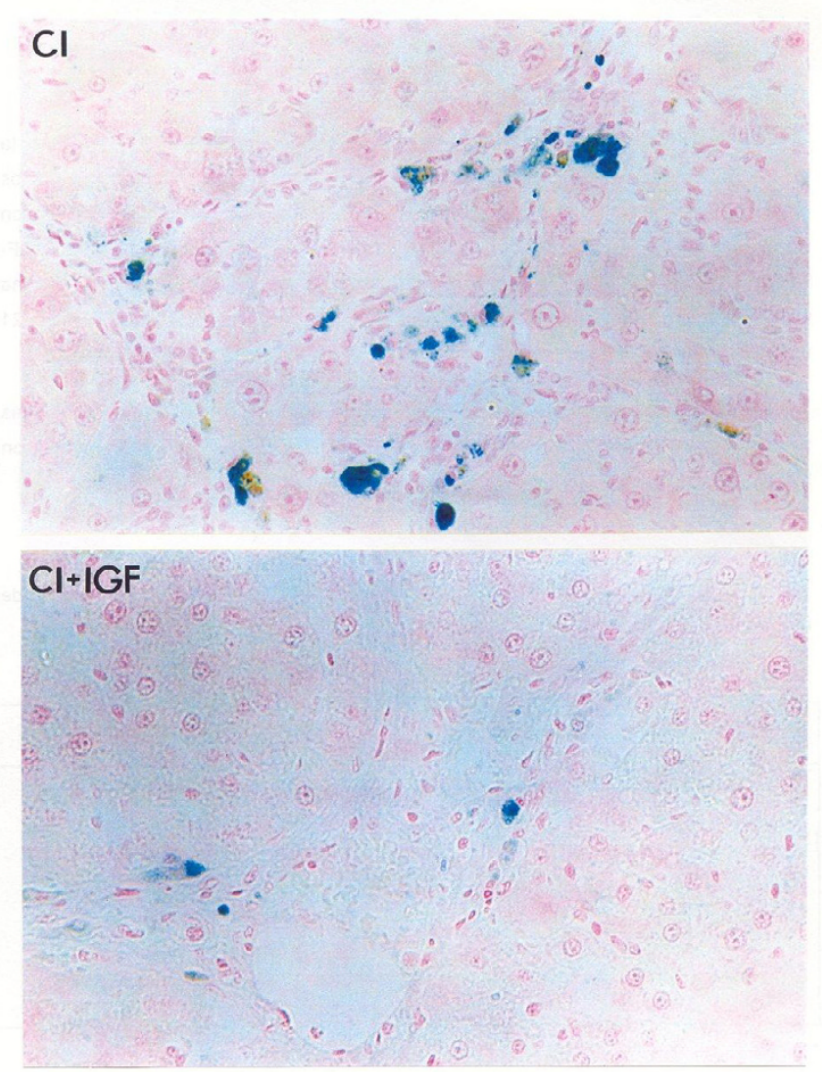

\section{Figure I}

Perl's Prussian Blue staining for ferric iron (original magnification $\times 150)$ in the liver of an untreated cirrhotic rat $(\mathrm{Cl}$ group) and a cirrhotic animal treated with IGF-I. The $\mathrm{Cl}$ preparation was scored as 3 points (see Methods) and the section from $\mathrm{Cl}+\mathrm{IGF}$ group was scored with I point. No staining was found in control group (CO).

In order to find a relationship between the studied parameters and oxidative liver damage, MDA levels, an index of lipid peroxidation, were evaluated [29]. Hepatic levels of MDA ( $\mathrm{nmol} / \mathrm{mg}$ protein) were increased in untreated cirrhotic rats compared with control group $(\mathrm{CI}=1.741 \pm$ $366 ; \mathrm{CO}=0.565 \pm 0.030 ; \mathrm{p}<0.05$ ) as it was previously reported in similar protocols $[14,16]$. This marker of lipid peroxidation was again reduced in CI+IGF $(0.99 \pm 0.11$ $\mathrm{nmol} / \mathrm{mg}$ protein, $\mathrm{p}=\mathrm{ns}$ vs controls). A significant direct correlation was found between hepatic iron and hepatic MDA levels (see Figure 3, $r=0.857 \mathrm{p}<0.001$ ). In addition, MPO correlated with hepatic levels of iron $(\mathrm{r}=$ $0.719, \mathrm{p}<0.001)$, iron content with hepatic ferritin $(\mathrm{r}=$ $0.656, \mathrm{p}<0.001)$ and hepatic levels of $\mathrm{Cu}$ with MDA $(0.649 \mathrm{p}<0.01)$.

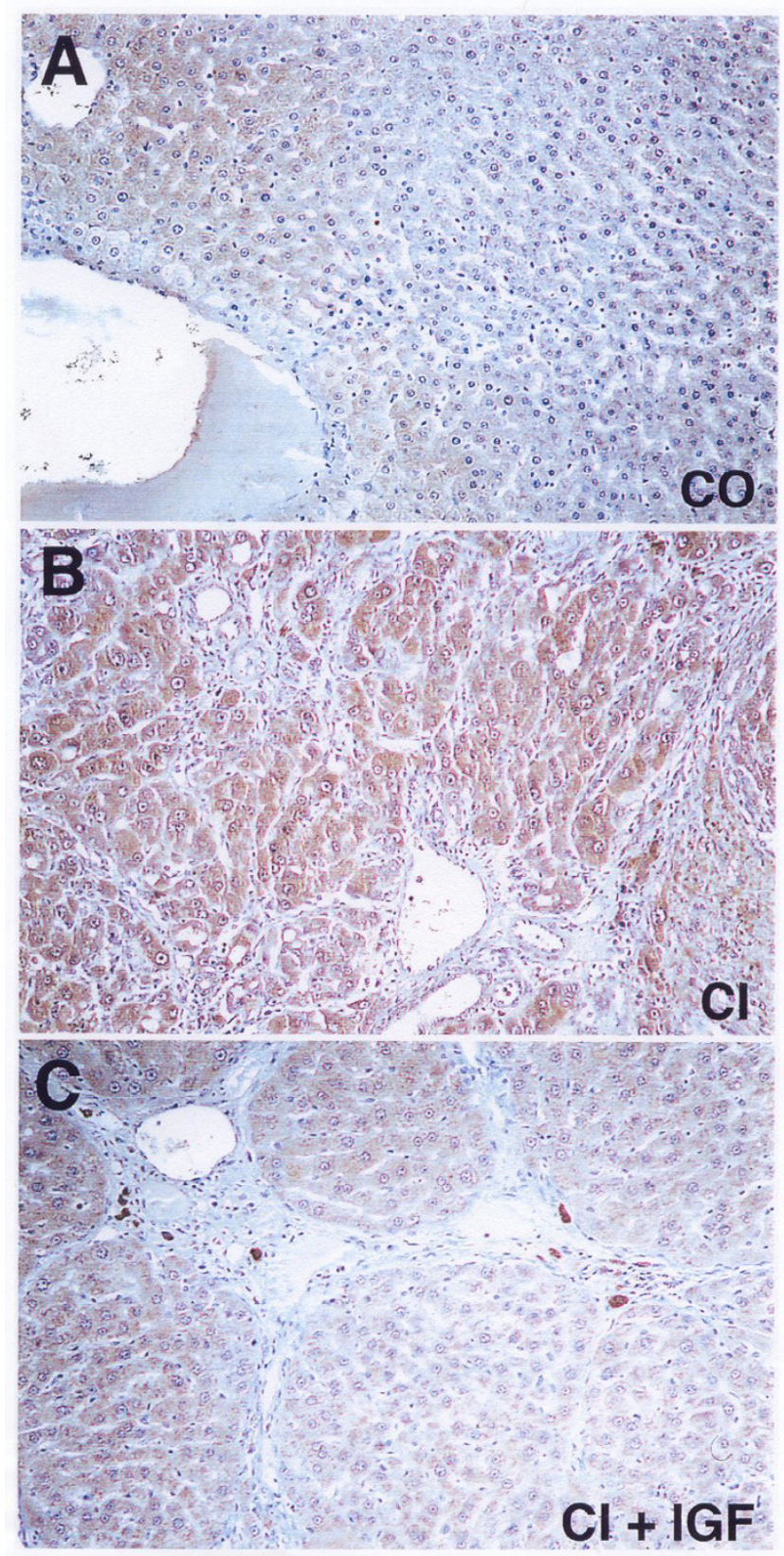

\section{Figure 2}

Immunostaining for iNOS in liver from: $\mathrm{A}$, healthy control group (CO); B, untreated cirrhotic group (Cl); C, cirrhotic animals treated with IGF-I for three weeks. An increased iNOS immunoreactivity was observed in hepatocytes from $\mathrm{Cl}$ group, compared to controls and $\mathrm{Cl}+\mathrm{IGF}$ groups. These two pictures (B and $C$ ) correspond to two animals from each cirrhotic group that presented the most severe cirrhosis. Although in this section (C, Cl+lGF) from a series with decompensated cirrhosis can be observed thick collagen septa, it is also clear the hepatoprotective effect of the IGF-Itherapy versus untreated cirrhotic group (B). 


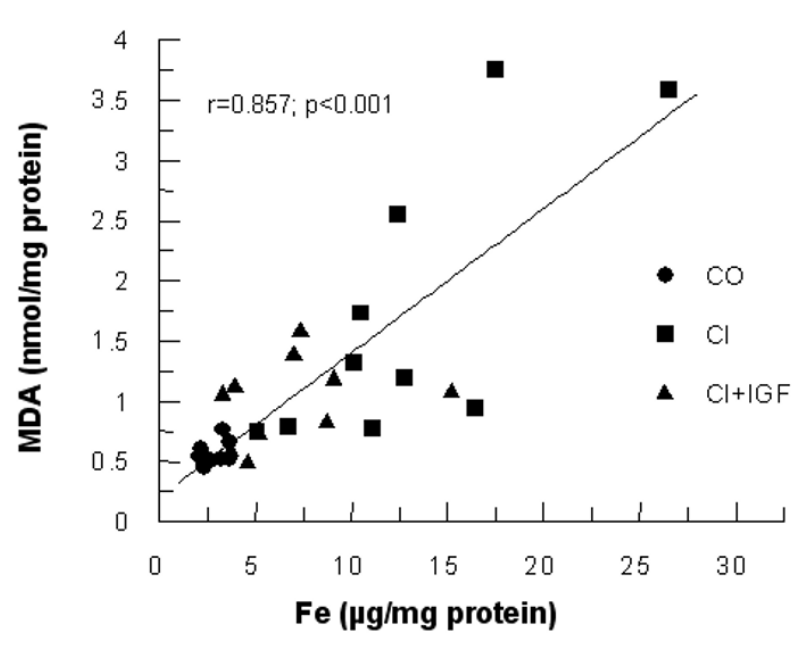

Figure 3

Correlation between hepatic iron content and hepatic MDA levels, a marker of lipid peroxidation (Sperman $r=0.857, p<$ 0.001 , two tails).

\section{Discussion}

These results show that the treatment with low doses of IGF-I induces a reduction of all studied parameters involved in oxidative damage mechanisms in this model of cirrhosis. These findings support the hepatoprotective and antifibrogenic effects previously reported [14,16]. This study also provides evidence for the involvement of oxidative stress in the cell injury occurring in $\mathrm{CCl}_{4^{-}}$ induced cirrhosis associated with iron and copper overload and an increase of myeloperoxidase and iNOS expression.

It is well known that iron and copper promote oxidant forces $[17,18,21,30]$. Oxidant stress is considered present when there is either an overproduction of free radicals or a significant diminution in antioxidant defenses, the result of either being excessive levels of free radicals $[29,31]$. In both iron and copper storage disorders, generation of free radicals and depletion of antioxidants may be critical factors determining the intensity of liver injury $[18,19,30,31]$. In a previous work we showed that antioxidant enzymes (superoxide dismutase, SOD, Glutathione peroxidase, GSHPx, and catalase) were reduced in the liver of cirrhotic animals and improved by low doses of IGF-I administration [14]. Of interest, in the present study we demonstrate that hepatic levels of iron and copper metals (both involved in oxidative damage), increased in untreated cirrhotic rats, reverted to normal levels after IGF-I treatment.
Free iron (or low molecular iron or chelatable iron pool) facilitates the decomposition of lipid hydroperoxides resulting in lipid peroxidation and induces the generation of $\mathrm{OH}$ radicals and also accelerates the nonenzymatic oxidation of glutathione to form $\mathrm{O}_{2}{ }^{*}$ - radicals $[18,19,30,32]$. The direct and significant correlation between lipid peroxidation and hepatic iron content presented here provides new evidence of the relationship between these parameters.

Most of the body's iron is tightly bound to transferrin, entering cells via receptor-mediated endocytosis. Transferrin avidly binds 2 moles of $\mathrm{Fe}^{3+}$ per mole of protein [32]. Normally the average of transferrin iron saturation is about one third of the full capacity, thereby ensuring that there is virtually no free iron circulating in the extracellular fluids. At pH 7.4, the iron-transferrin complex does not participate in the Fenton reaction. Under more acidic conditions, the complex breaks down with release of iron. This is of important physiological relevance, since the iron-transferrin complex, within endocytotic vesicles, is subjected to an acidic environment (pH 5-6). Intracellular iron released from transferrin is rapidly incorporated into ferritin, minimizing its inherent toxicity [17,30,31]. Iron can be released from the ferritin within the cell by a number of factors that occur in inflammation: acidic $\mathrm{pH}$, proteolysis, myeloperoxidase, $\mathrm{NO}, \mathrm{O}_{2}{ }^{{ }^{-}-}$, etc. [33]. Enhanced degradative proteolysis, which also occurs in oxidative stress, may lead to proteolytic modification of ferritin, causing an increase in cellular iron. Although in this study free iron could not be quantified, all of the factors certainly involved in inducing an increase of free iron pool appeared elevated in untreated cirrhotic rats (MPO, iNOS, $\mathrm{Cu}, . .$.$) and returned to normal levels after IGF-I-$ treatment.

In the present study, we have found that hepatic transferrin and ferritin levels increased in cirrhotic rats with a parallel rise in iron deposition, whereas in cirrhotic rats treated with IGF-I all the above-mentioned parameters appeared diminished (see Table 1 and Figure 1).

High serum ferritin levels and hepatic iron storage have also been reported in hepatitis $B$ virus and hepatitis $C$ virus-related chronic hepatitis and alcoholic liver disease $[26,34,35]$. It has also been shown that iron induces ferritin biosynthesis [21,22,35-39]. A result here presented shows a direct correlation between hepatic iron and ferritin levels which is consistent with the over-mentioned Authors statements.

In liver cirrhosis the increase in iron content is not a real iron overload as in hemochromatosis, because iron is stored mainly inside the macrophages [40]. In agreement with this data, the present work shows that the iron scores 
detected in this experimental model of cirrhosis were found in Kupffer cells, as it is shown in Fig. 1.

Transferrin is mainly produced by the liver when hepatic regeneration takes place, as occurs in cirrhosis $[37,41,42]$. Thus, the reported increase of transferrin in untreated cirrhotic animals could be due to regeneration. However, cellular proliferation does not explain our findings, because in a parallel study in this series we showed that cellular proliferation (assessed by PCNA expression) was higher in IGF-treated cirrhotic animals [15] than those which showed lower hepatic levels of transferrin. Therefore, the hepatoprotective effect of IGF-I in cirrhotic animals could be mediated partly by enhancing the endogenous regenerative response, aimed al the restoration of functional liver mass [14]. In the present work, the described increase of transferrin in untreated cirrhotic animals seems to be a defensive response to the enhanced iron content $[17,18,21,22,32]$.

On the other hand, the mechanisms responsible for the effects of IGF-I described in this article are not fully understood. The beneficial effects of IGF-I could be a result of many properties of this hormone that require further investigation. The well known erythropoietic activity of IGF-I $[43,44]$ could even contribute to an extrahepatic utilization of iron, decreasing its storage in the liver.

Hepatic copper overload leads to progressive liver injury and eventually cirrhosis in Wilson disease and Indian childhood cirrhosis [45]. Copper is absorbed into the intestine and transported by albumin to the liver. Any excess in copper levels is excreted into the bile mainly through a lysosome-to-bile pathway. Hepatic copper accumulation results from a reduction in the bile excretion of copper, as occurs in patients with Wilson disease, biliary obstruction, or other types of cholestasis [45]. Cirrhotic animals included in this protocol showed severe cholestasis after receiving $\mathrm{CCl}_{4}$ for 30 weeks. As previously reported [14] IGF-I-treatment induced a reduction in cholestasis parameters (serum levels of bilirubin, alkaline phosphatase and cholesterol). This may account for explanation of the decreased copper hepatic content revealed in the present work.

After hepatic injury, several kinds of cells (endothelial cells, Kuppfer cells, and circulating platelets, neutrophils and monocytes) are activated in the subsequent inflammatory response [23]. Free radicals produced mainly by macrophages cause local tissue damage in inflammatory conditions [23,31]. Neutrophil and monocyte activation is a critical step in both the host defense system against microorganisms and the inflammatory response. When neutrophils are activated, they begin to produce superoxide radicals $\left(\mathrm{O}_{2}{ }^{*}\right)$ and secrete myeloperoxidase
(MPO) [23]. The majority of the $\mathrm{O}_{2}{ }^{*}$ - formed during this respiratory burst is converted to the bactericidal oxidant hypochlorous acid $(\mathrm{HOCl})$ via a series of reactions catalyzed by superoxide dismutase and MPO [23,29]. Numerous MPO-expressing cells have been detected in fibrous septa of human cirrhotic livers [46]. MPO has been identified as a component of human Kupffer cells [46]. The same authors suggest that the oxidative damage resulting from the action of MPO may contribute to acute liver injury and hepatic fibrogenesis [46]. In our study, the increase of MPO in cirrhotic animals and its decrease in those treated with IGF-I suggests an anti-inflammatory effect of this hormone.

Another result which deserves particular mention is that iNOS expression was significantly lower in cirrhotic rats treated with IGF-I compared to untreated cirrhotic animals. This finding is in accordance with those reported by other groups [47-53]. However the versatility of this molecule, small changes in the experimental conditions or the studied cell line can show results that seem to be an apparently contradiction [54-58]. For example, in our experience, we did not find a similar response in early stage of cirrhosis animals (data not shown). Probably, in early stages of cirrhosis NO induces an improvement in parenchyma irrigation by vasodilatation, but in advanced liver cirrhosis, where exist thick collagen septa, the increase of $\mathrm{NO}$ results to lead enhancing oxidative damage by $\mathrm{N}$ derived radicals.

\section{Conclusion}

In conclusion, these results show that the hepatoprotective and antifibrogenic effect of IGF-I in rats with liver cirrhosis is associated with a significant reduction of the hepatic levels of several parameters such as $\mathrm{Fe}, \mathrm{Cu}, \mathrm{MPO}$, iNOS, ferritin and transferring, all of them involved in oxidative damage. In this work, iron and copper overload have been demonstrated in the liver from rats with $\mathrm{CCl}_{4}$ induced cirrhosis. The hepatic levels of both metals diminished in cirrhotic animals treated with IGF-I. MPO content, iNOS immunohistological expression and hepatic ferritin and transferrin levels were increased in untreated animals and returned to normal in cirrhotic animals treated with IGF-I.

The IGF-I effects described in the present study suggest that a therapeutical approach targeted at lowering oxidative stress marker levels could be effective in the chronic liver disease.

\section{Abbreviations}

IGF-I, insulin-like growth factor-I; $\mathrm{Fe}$, iron; $\mathrm{Cu}$, cooper; MDA, malondialdehyde; CO, control healthy group; $\mathrm{CI}$, untreated cirrhotic rats; CI + IGF, IGF-treated cirrhotic 
rats; $\mathrm{O}_{2}{ }^{*}$-, superoxide radicals; $\mathrm{MPO}$, myeloperoxidase; iNOS, inducible nitric oxide synthase; AU, arbitrary units.

\section{Competing interests}

The author(s) declare that they have no competing interests.

\section{Authors' contributions}

MG: Analytical studies, hypothesis and paper elaboration.

ICC: Experimental design and treatment (induction of liver cirrhosis and IGF-I administration), hypothesis, histopathological study and scores.

MDS: Analytical studies and in vivo assay.

IN: Atomic absorption spectrometry assay.

JEP: In vivo assay.

AC: Hypothesis and experimental design and revision.

ADC: Experimental treatment and documentation.

EC: Histopathological study and measurements.

\section{SGB: Revision.}

\section{Acknowledgements}

The authors wish to express their gratitude to Bruce Scharschmidt (Chiron), for generously granting the rhIGF-I used in this study. We are as well deeply indebted to Mr. J. Celaya and "Fundación Echébano" for their financial collaboration, Dr. Daniela Ceccarelli for the helpful discussion and Mr. Paul Golden for the English manuscript review.

\section{Supported by the Spanish Program I+D, SAF 2001/1672.}

\section{References}

I. Sara VR, Hall K: Insulin-like growth factor-I and their binding proteins. Physiol Rew 1990, 70:591-613.

2. Caufriez A, Reding P, Urbain D, Goldstein J, Copinschi G: Insulinlike growth factor-I: a good indicator of functional hepatoceIular capacity in alcoholic liver cirrhosis. J Endocrinol Invest I99I, 14:317-32I.

3. Hattori N, Kurahachi H, Ikekubo K, Ishihara T, Moridera K, Hino M, Saiki $Y$, Imura H: Serum growth hormone-binding protein, insulin-like growth factor-I, and growth hormone in patients with liver cirrhosis. Metabolism 1992, 41:377-38I.

4. Möller S, Becker U, Juul A, Skakkebæk NE, Christensen E, Group E: Prognostic Value of Insulin-like Growth Factor-I ans its Binding Proteins in patients with alcohol-induced Liver disease. Hepatology 1996, 23:1073-1078.

5. Schimpff RM, Lebrec D, Donadieu M: Somatomedin production in normal adults and cirrhotic patients. Acta Endocrinol 1977, 86:355-362.

6. Picardi A, De Oliveira AC, Muguerza B, Tosar A, Quiroga J, CastillaCortazar I, Santidrian S, Prieto J: Low doses of insulin-like growth factor-I improve nitrogen retention and food efficiency in rats with early cirrhosis. J Hepatol 1997, 26:191-202.

7. Castilla-Cortázar I, Prieto J, Urdaneta E, Pascual M, Nuñez M, Zudaire E, García M, Quiroga J, Santidrián S: Impaired intestinal sugar transport in cirrhotic rats: correction by low doses of insulinlike growth factor I. Gastroenterology 1997, I I 3: I I80- I I87.
8. Castilla-Cortázar I, Picardi A, Ainzua J, Urdaneta E, Tosar A, García $M$, Quiroga J, Prieto J: Effect of insulin-like growth factor $I$ on in vivo intestinal absorption in cirrhotic rats. Am J Physiol 1999 , 276:G637-G642.

9. Castilla-Cortazar I, Garcia M, Quiroga J, Diez N, Diez-Caballero F, Calvo A, Diaz M, Prieto J: Insulin-like growth factor-I reverts testicular atrophy in rats with advanced cirrhosis. Hepatology 2000, 31:592-600.

10. Pascual M, Castilla-Cortazar I, Urdaneta E, Quiroga J, Garcia M, Picardi A, Prieto J: Altered intestinal transport of amino acids in cirrhotic rats: the effect of insulin-like growth factor-I. Am J Physiol Gastrointest Liver Physiol 2000, 279:319-324.

II. Cemborain A, Castilla-Cortázar I, García M, Quiroga J, Muguerza B, Picardi A, Santidrián S, Prieto J: Osteopenia in rats with liver cirrhosis: beneficial effects of IGF-I treatment. J Hepatol 1998, 28: $|22-| 3 \mid$

12. Cemborain A, Castilla-Cortazar I, Garcia M, Muguerza B, Delgado G, Diaz-Sanchez M, Picardi A: Effects of IGF-I treatment on osteopenia in rats with advanced liver cirrhosis. J Physiol Biochem 2000, 56:91-99.

13. Castilla-Cortazar I, Aliaga-Montilla MA, Salvador J, Garcia M, Delgado G, Gonzalez-Baron S, Quiroga J, Prieto J: Insulin-like growth factor-I restores the reduced somatostatinergic tone controlling growth hormone secretion in cirrhotic rats. Liver 200I, 21:405-409.

14. Castilla-Cortázar I, García M, Muguerza B, p érez R, Quiroga J, Santidrián S, Prieto J: Hepatoprotective Effects of Insulin-like Growth Factor-I in Rats with Carbon-Tetrachloride-Induced Cirrhosis. Gastroenterology 1997, I I 3:1682-169I.

15. Mirpuri E, Garcia-Trevijano ER, Castilla-Cortazar I, Berasain C, Quiroga J, Rodriguez-Ortigosa C, Mato JM, Prieto J, Avila MA: Altered liver gene expression in CCl4-cirrhotic rats is partially normalized by insulin-like growth factor-I. Int J Biochem Cell Biol 2002, 34:242-252.

16. Muguerza B, Castilla-Cortazar I, Garcia M, Quiroga J, Santidrian S, Prieto J: Antifibrogenic effect in vivo of low doses of insulin-like growth factor-I in cirrhotic rats. Biochim Biophys Acta 200I, 1536: 185-195.

17. Bacon BR, Britton RS: Hepatic injury in chronic iron overload. Role of lipid peroxidation. Chem Biol Interactions 1989, 70: 183-226.

18. Sokol RJ: Antioxidant Defenses in Metal-Induced Liver Damage. Semin Liver Dis 1996, 16:39-46.

19. Stohs SJ, Bagchi D: Oxidative mechanisms in the toxicity of metal ions. Free Radical Biol Med 1995, 18:321-336.

20. Arora AS, Gores G]: The role of metals in ischemia/reperfusion injury of the liver. Semin Liver Dis 1996, 16:31-38.

21. Bonkovsky HL, Banner BF, Lambrecht RW, Rubin RB: Iron in Liver Diseases other than Hemochromatosis. Semin Liver Dis 1996, 16:65-82.

22. Hubert N, Lescoat G, Sciot R, Moirand R, Jego P, Leroyer P, Brissot $P$ : Regulation of ferritin and transferrin receptor expression by iron in human hepatocyte cultures. J Hepatol 1993, I8:30I-3I2.

23. Rosen GM, Pou S, Ramos AL, Cohen MS, Britigan BE: Free radicals and phagocytes cells. Faseb J 1995, 9:200-209.

24. National Academy of Sciences: The Guiding principles for research involving animals. Washington, DC: National Institutes of Health; 1991.

25. Farinati F, Cardin R, De Maria N, Libera G, Marafin C, Lecis E, Burra $P$, Florean A, Cecchetto A, Naccarato R: Iron storage, lipid peroxidation and glutathione turnover in chronic anti-HCV positive hepatitis. J Hepatol 1995, 22:449-456.

26. Boucher E, Bourienne A, Adams $P$, Turlin B, Brissot $P$, Deugnier $Y$ : Liver iron concentration and distribution in chronic hepatitis C before and after interferon treatment. Gut 1997, 4 I : I I 5- I 20.

27. Shu S, Ju G, Fan LZ: The glucose oxidase-DAB-nickel method in peroxidase histochemistry of the nervous system. Neurosci Lett 1988, 85:169-171.

28. Bradford MM: A rapid and sensitive method for the quantitation of microgram quantities of protein utilizing the principle of protein-dye binding. Anal Biochem 1976, 72:248-254.

29. Gutteridge JMC: Lipid peroxidation and antioxidants as biomarkers of tissue damage. Clin Chem 1995, 41: I819-1828.

30. Yu BP: Cellular defenses against damage from reactive oxygen species. Physiol Rev 1994, 74:139-162. 
31. Rosser BG, Gores G]: Liver cell necrosis: cellular mechanisms and clinical implications. Gastroenterology 1995, 108:252-275.

32. Bacon BR, Britton RS: The pathology of hepatic iron overload: a free radical - mediated process? Hepatology 1990, I I:127-37.

33. Trinder D, Macey DJ, Olynyk JK: The new iron age. Int J Mol Med 2000, 6:607-612

34. Beinker NK, Voigt MD, Arendse M, Smit J, Stander IA, Kirsch RE: Threshold effect of liver iron content on hepatic inflammation and fibrosis in hepatitis B and C. J Hepatol 1996, 25:633-638.

35. Haque S, Chandra B, Gerber MA, Lok AS: Iron overload in patients with chronic hepatitis C: a clinicopathologic study. Hum Pathol 1996, 27:|277-|28I.

36. Cairo G, Tacchini L, Pogliaghi G, Anzon E, Tomasi A, Bernelli-Zazzera $A$ : Induction of ferritin synthesis by oxidative stress. Transcriptional and post-transcriptional regulation by expansion of the "free" iron pool. J Biol Chem 1995, 270:700-703.

37. Halliwell B, Gutteridge JMC: Free Radicals in Biology and Medicine. New York: Oxford University Press; 1989.

38. Dix DJ, Lin PN, Mckenzie AR, Walden WE, Theil EC: The influence of the base-paired flanking region on structure and function of the ferritin mRNA Iron Regulatory Element. J Mol Biol 1993, 23 I:230-240.

39. Schalinske K, Chen OS, Eisenstein RS: Iron Differentially translation of mitochondrial aconitase and ferritin mRNAs in mammalian cells. J Biol Chem 1998, 273:3740-3746.

40. Dhumeaux D, Hezode C: [Iron overload and liver diseases (except for hemochromatosis and dysmetabolic hepatosiderosis]. Bull Acad Natl Med 2000, 184:349-354.

41. Cairo G, Tacchini L, Pietrangelo A: Lack of coordinate control of ferritin and transferrin receptor expression during rat liver regeneration. Hepatology 1998, 28: 173-178.

42. Sunstrom NA, Gay RD, Wong DC, Kitchen NA, Deboer L, Gray PP: Insulin-like growth factor-I and transferrin mediate growth and survival of Chinese hamster ovary cells. Biotechnol Prog 2000, 16:698-702.

43. Merchav S: The haematopoietic effects of growth hormone and insulin-like growth factor-I. J Pediatr Endocrinol Metab 1998 I I:677-685

44. Panzenbock B, Bartunek P, Mapara MY, Zenke M: Growth and differentiation of human stem cell factor/erythropoietindependent erythroid progenitor cells in vitro. Blood 1998, 92:3658-3668.

45. Sternlieb I: Copper and Zinc. In The Liver Biology and Pathobiology Edited by: Arias IM, Boyer JL, Fausto N. New York: Raven Press; 1994:585-596.

46. Brown KE, Brunt EM, Heinecke JW: Immunohistochemical detection of myeloperoxidase and its oxidation products in Kupffer cells of human liver. Am J Pathol 200I, I 59:208I-2088.

47. Wang H, Chen XP, Qiu FZ: Salviae miltiorrhizae ameliorates cirrhosis and portal hypertension by inhibiting nitric oxide in cirrhotic rats. Hepatobiliary Pancreat Dis Int 2003, 2(3):39|-396.

48. Bhimani EK, Serracino-Inglott F, Sarela Al, Batten JJ, Mathie RT: Hepatic and mesenteric nitric oxide synthase expression in a rat model of $\mathrm{CCl}(4)$-induced cirrhosis. J Surg Res 2003, II3(1):172-178.

49. Mohammed NA, Abd El-Aleem S, Appleton I, Maklouf MM, Said M, McMahon RF: Expression of nitric oxide synthase isoforms in human liver cirrhosis. J Pathol 2003, 200(5):647-655.

50. Helmy A, Newby DE, Jalan R, Hayes PC, Webb DJ: Enhanced vasodilatation to endothelin antagonism in patients with compensated cirrhosis and the role of nitric oxide. Gut 2003 52(3):4|0-4I5.

5I. Yang W, Benjamin IS, Moore K, Portmann B, Alexander B: The action of nitric oxide on hepatic haemodynamics during secondary biliary cirrhosis in the rat. Eur J Pharmacol 2003, $46 I(I): 4 I-48$.

52. Koruk M, Aksoy H, Akcay F, Onuk MD: Antioxidant capacity and nitric oxide in patients with hepatic cirrhosis. Ann Clin Lab Sci 2002, 32(3):252-256.

53. Arkenau HT, Stichtenoth DO, Frolich JC Manns MP, Boker KH: Elevated nitric oxide levels in patients with chronic liver disease and cirrhosis correlate with disease stage and parameters of hyperdynamic circulation. Z Gastroenterol 2002, 40(II):907-9I3.

54. Gonzalez-Abraldes J, Garcia-Pagan JC, Bosch J: Nitric oxide and portal hypertension. Metab Brain Dis 2002, I 7((4)):3 I -324.
55. Loureiro-Silva MR, Cadelina GW, Iwakiri Y, Groszmann RJ: A liverspecific nitric oxide donor improves the intra-hepatic vascular response to both portal blood flow increase and methoxamine in cirrhotic rats. J Hepatol 2003, 39(6):940-946.

56. Van De Casteele M, Van Pelt JF, Nevens F, Fevery J, Reichen J: Low NO bioavailability in $\mathrm{CCl}_{4}$ cirrhotic rat livers might result from low NO synthesis combined with decreased superoxide dismutase activity allowing superoxide-mediated NO breakdown: A comparison of two portal hypertensive rat models with healthy controls. Comp Hepatol 2003, I 0(2(I)):2.

57. Bellis L, Berzigotti A, Abraldes JG, Moitinho E, Garcia-Pagan JC, Bosch J. Rodes ]: Low doses of isosorbide mononitrate attenuate the postprandial increase in portal pressure in patients with cirrhosis. Hepatology 2003, 37(2):378-384.

58. Rockey DC, Chung J]: Reduced nitric oxide production by endothelial cells in cirrhotic rat liver: endothelial dysfunction in portal hypertension. Gastroenterology 1998, I I 4(2):344-5I.

\section{Pre-publication history}

The pre-publication history for this paper can be accessed here:

http://www.biomedcentral.com/1471-230X/5/7/prepub

Publish with BioMed Central and every scientist can read your work free of charge

"BioMed Central will be the most significant development for disseminating the results of biomedical research in our lifetime. "

Sir Paul Nurse, Cancer Research UK

Your research papers will be:

- available free of charge to the entire biomedical community

- peer reviewed and published immediately upon acceptance

- cited in PubMed and archived on PubMed Central

- yours - you keep the copyright
BioMedcentral 